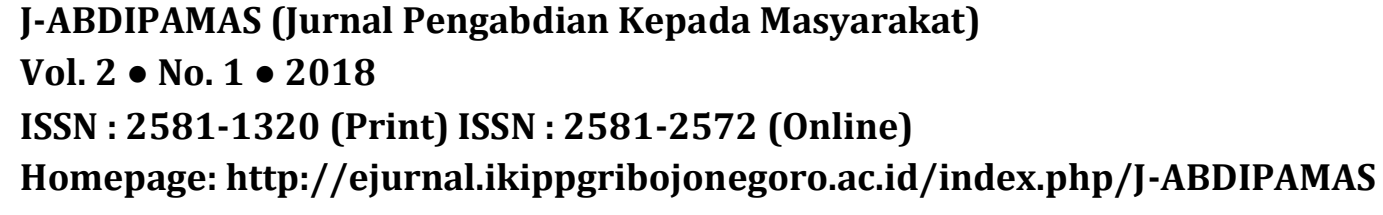

\title{
PELATIHAN KEMAMPUAN E-LEARNING GURU MATEMATIKA DENGAN MENGGUNAKAN DENGAN MOODLE
}

\author{
Syariful Fahmi ${ }^{1}$, Sofi Widyanesti Priwantoro ${ }^{2}$, Burhanudin Arif Nur Nugroho ${ }^{3}$ \\ ${ }^{1}$ Universitas Ahmad Dahlan. Email: syarifulfahmi@gmail.com \\ 2 Universitas Ahmad Dahlan. Email: soffidyan@gmail.com \\ 3 Universitas Ahmad Dahlan. Email: burhanarifmath@gmail.com
}

\begin{abstract}
The ability of teachers to teach influenced by ability in technology in the learning process. E-learning as one form of technology will help teachers in the process of teaching and learning. Therefore the ability of e-learning mastery teachers becomes key words in the activities of e-learning in education. One form of E-learning is moodle. The purpose of this training is to provide skills for teachers of mathematics in developing media-based learning, moodle. Moodle is an application program that can modify a media learning into web forms. This application allows students to enter into the "digital classroom" to access learning materials. The participants of these activities is the mathematics teacher of SMP Muhammadiyah 1 Godean, SMP Muhammadiyah 1 Minggir, SMP Muhammadiyah 1 Gamping, SMP Muhammadiyah 1 Moyudan, SMP Muhamamdiyah 1 Depok and SMP Muhammadiyah 2 Depok. The method of training is giving lectures about moodle, the practice and accompaniment the creation of media-based learning, moodle. This training has managed to build the learning system with the concept of e-learning (electronic learning) or distance learning (distance learning). With this concept the system of teaching and learning will not be limited to space and time. A teacher can give a lecture learning materials from anywhere. Similarly, a student can follow lectures from anywhere.
\end{abstract}

Keywords: E-Learning Moodle

\begin{abstract}
ABSTRAK
Kemampuan mengajar guru salah satunya dipengaruhi oleh kemampuan penggunaan teknologi dalam proses pembelajaran di kelas. E-learning sebagai salah satu bentuk teknologi akan membantu guru dalam proses belajar mengajar. Oleh karena itu kemampuan penguasaan e-learning guru menjadi kata kunci dalam kegiatan e-learning dalam pendidikan. Salah satu bentuk E-learning adalah dengan menggunakan moodle. Tujuan dari pelatihan ini adalah memberikan ketrampilan bagi guru-guru matematika dalam mengembangkan media pembelajaran berbasis moodle. Moodle merupakan program aplikasi yang dapat merubah sebuah media pembelajaran kedalam bentuk web. Aplikasi ini memungkinkan siswa untuk masuk kedalam "ruang kelas digital" untuk mengakses materi-materi pembelajaran. Peserta kegiatan ini adalah para guru matematika dari SMP Muhammadiyah 1 Godean, SMP Muhammadiyah 1 Minggir, SMP Muhammadiyah 1 Gamping, SMP Muhammadiyah 1 Moyudan, SMP Muhamamdiyah 1 Depok dan SMP Muhammadiyah 2 Depok. Metode pelatihan adalah dengan ceramah tentang moodle, praktek secara langsung dan pendampingan pembuatan media pembelajaran berbasis moodle. Pelatihan ini telah berhasil membangun sistem pembelajaran dengan konsep e-learning (pembelajaran secara elektronik) ataupun distance learning (pembelajaran jarak jauh). Dengan konsep ini sistem belajar mengajar akan tidak terbatas ruang dan waktu. Seorang guru dapat memberikan materi pembelajaran kuliah dari mana saja. Begitu juga
\end{abstract}

Kata Kunci: E-Learning Moodle 


\section{PENDAHULUAN}

Media pembelajaran dalam proses pembelajaran memegang peranan penting sebagai alat bantu untuk menciptakan proses belajar yang efektif. Association of education and Communication Technology (AECT) menyatakan bahwa media adalah segala bentuk yang digunakan untuk menyalurkan informasi (Anita, 2008:1). Media pembelajaran akan membantu belajar matematika yang sebagian siswa menganggap sebagai mata pelajaran yang sulit. Pembelajaran matematika memiliki fungsi sebagai sarana untuk mengembangkan kemampuan berpikir kritis, logis, kreatif, dan bekerja sama yang diperlukan siswa dalam kehidupan modern (NCTM, 2000). Kompetensi tersebut diperlukan agar peserta didik dapat memiliki kemampuan memperoleh, mengelola, dan memanfaatkan informasi untuk bertahan hidup pada keadaan yang selalu berubah, tidak pasti, dan kompetitif (Peraturan Menteri Pendidikan Nasional nomor. 22 tahun 2006 tentang standar isi).

Berdasarkan social constructionist pedagogy, cara terbaik untuk belajar adalah dari sudut pandang murid itu sendiri. Model pengajaran berorientasi objek (murid) ini berbeda dengan sistem pengajaran tradisional yang biasanya memberikan informasi atau materi yang dianggap perlu oleh pengajar untuk diberikan kepada murid. Tugas pengajar akan berubah dari sumber informasi menjadi orang yang memberikan pengaruh (influencer) dan menjadi contoh dari budaya kelas. Peran pengajar dalam sistem Moodle ini antara lain: berhubungan dengan muridmurid secara perorangan untuk memahami kebutuhan belajar mereka dan memoderatori diskusi serta aktivitas yang mengarahkan murid untuk mencapai tujuan belajar dari kelas tersebut. Salah satu teknik pembelajaran yang bisa digunakan dalam pembelajaran Matematika yang memberikan kesempatan kepada siswa untuk belajar kreatif, dan lebih aktif adalah dengan teknik pembelajaran menggunakan media pembelajaran dalam bentuk teknologi komputer berbasis elearning. Salah satu program untuk mengembangkan e-learning adalah program Moodle. Fokus proyek Moodle adalah menyediakan bagi guru / pendidik alat (tool) terbaik untuk mengelola dan mempromosikan kegiatan belajar. Moodle memiliki fitur yang memungkinkan untuk skala penyebaran yang sangat besar dan ratusan ribu siswa, namun juga bisa digunakan untuk sekolah dasar atau kegiatan belajar skala kecil lainnya (Kadek, 2014). Banyak institusi menggunakannya sebagai platform mereka untuk melakukan kursus sepenuhnya online, sementara beberapa menggunakannya hanya untuk menambah kursus tatap muka (dikenal sebagai blended learning). Banyak pengguna Moodle suka menggunakan modul kegiatan (seperti forum, database dan wiki) untuk membangun komunitas kolaboratif untuk belajar intensif sekitar materi pelajaran (dalam tradisi konstruksionis sosial), ataupun menggunakan Moodle sebagai cara untuk menyampaikan konten untuk mahasiswa (seperti paket SCORM standar) dan menilai pembelajaran menggunakan tugas atau kuis.

SMP Muhammadiyah yang berada di kabupaten Sleman, khususnya di wilayah barat antara lain SMP Muhammadiyah 1 Godean, SMP Muhammadiyah 1 Minggir, SMP Muhammadiyah 1 Gamping, SMP Muhammadiyah 1 Moyudan, SMP Muhamamdiyah 1 Depok dan SMP Muhammadiyah 2 Depok. Sekolah tersebut sudah memilki laboratorium komputer sehingga penggunaan e-learning akan meningkatkan penggunaan laboratorium komputer.

Penggunaan komputer untuk proses e-learning menggunakan moodle dalam belajar matematika memegang peranan penting sebagai media untuk menciptakan belajar mengajar yang efektif dan efisien. Adanya e-learning akan mempermudah guru dan siswa dalam menerima pelajaran matematika dan juga mempertinggi mutu belajar mengajar (Richardson, 2008). Pada pembelajaran matematika dengan menggunakan e-learning akan menjadikan siswa belajar melalui pengalaman dan berbuat sendiri. 
Dari analisis situasi yang telah diuraikan diatas, dapat diidentifikasi permasalahanpermasalahan sebagai berikut: 1) Sekolah belum pernah melakukan proses balajar mengajar dengan menggunakan e-learning. 2) Guru tidak punya atau kurang waktu dalam membuat media pembelajaran berbasis e-learning. 3) Guru belum memiliki kemampuan dalam menggunakan moodle. Sementara tujuan dari kegiatan ini adalah untuk Melatih guru-guru matematika dalam pembuatan media pembelajaran moodle dan melakukan evaluasi bersama peserta terhadap pelatihan yang sudah dilakukan.

\section{METODE PELAKSANAAN}

Pengabdian masyarakat ini dilakukan dengan terlebih dulu mencermati permasalahan yang ada di lapangan untuk mencari tahu bagaiamana pengetahuan peserta terhadap seluk beluk media pembelajaran, pengetahuan akan e-learning, serta moodle. Setelah diidentifikasi permasalahan yang ditemui maka selanjutnya diadakan workshop atau pelatihan bagi guru matematika di SMP Muhammadiyah se-kecamatan Godean dan kecamatan Depok. Materi pelatihan pembuatan e-learning dengan program moodle, pembuatan materi pembelajaran matematika dengan geogebra serta pembuatan modul penggunaan media pembelajaran berbasis e-learning dengan menggunakan moodle dan geogebra. Pengabdian masyarakat ini dilakukan dengan menggunakan metode pendampingan, pelatihan dan penyampaian materi (ceramah). Materi pelatihan yang disampaikan adalah sebagai berikut:

1. Menggunakan fungsi dasar moodle dan kegunaannya,

2. Membuat domain e-learning dengan menggunakan moodle,

3. Membuat materi pembelajaran dan soal-soal untuk dimasukan dalam moodle.

\section{HASIL DAN PEMBAHASAN}

Berikut hasil yang telah dicapai dalam pelaksanaan pelatihan penggunaan $e$ learning dengan menggunakan moodle untuk guru matematika di SMP Muhammadiyah se-kecamatan Godean dan kecamatan Depok, Sleman, Yogyakarta. Kegiatan pelatihan dan pendampingan ini melibatkan dua orang dosen dan 4 mahasiswa dan bermitra dengan enam sekolah. Keanggotaan staf pengajar dipilih berdasarkan bidang keahlian yang dimiliki sehingga dapat menunjang kegiatan Pengabdian Masyarakat.

Pelatihan ini melibatkan guru-guru matematika dari SMP Muhammadiyah 1 Godean, SMP Muhammadiyah 1 Minggir, SMP Muhammadiyah 1 Gamping, SMP Muhammadiyah 1 Moyudan, SMP Muhamamdiyah 1 Depok dan SMP Muhammadiyah 2 Depok. Pelatihan dilakukan sebanyak 6 kali dan dilakukan pendampingan sebanyak 2 kali. Kegiatan diawali dengan koordinasi dengan masing-masing kepala sekolah dan guruguru yang terlibat dan dilanjutkan dengan pelatihan dengan lokasi di laboratorium computer SMP Muhammadiyah 1 Godean. Pertimbangan tempat di Laboratorium Komputer SMP Muhammadiyah 1 Godean adalah pertimbangan jarak yang memudahkan semua peserta untuk mengikuti pelatihan. Pelatihan dilakukan sebanyak tiga kali dalam satu minggu yaitu setiap hari kamis, jumat, dan sabtu dengan melibatkan 4 mahasiswa sebagai asisten pelatihan. Pada tahap evaluasi dan monitoring Tim pelaksana mengukur keberhasilan peran guru dalam membuat e-learning untuk mendukung proses pembelajaran matematika serta dianalisis hambatan untuk keberlanjutan kegiatan 
tersebut. Tersedianya laboratorium di SMP Muhammadiyah 1 Godean dapat membantu memfasilitasi kegiatan pengabdian masyarakat ini dengan memberikan kesempatan guru untuk belajar e-learning bagi guru-guru matematika serta pembuatan media pembelajaran matematika berbasis program moodle.

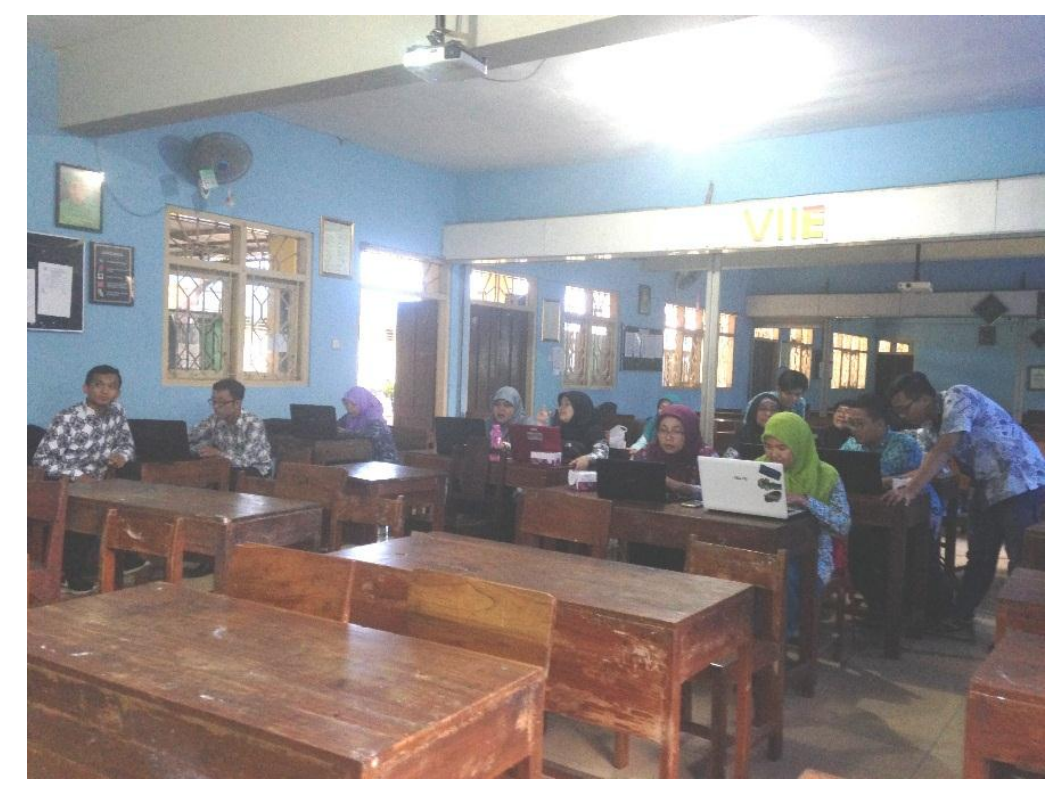

Gambar 1 Dokuentasi pelaksanaan pelatihan

Peserta pelatihan adalah sebanyak 13 guru-guru matematika. Peserta pelatihan juga melakukan evaluasi terhadap proses pelaksanaan pelatihan. Penilaian tersebut dilakukan dengan menggunakan angket. Hasil penilaian juga menunjukan 76,92\% dari peserta menyatakan pelatihan ini telah mampu memberdayakan guru sehingga mampu berkarya secara mandiri, 92.30\% peserta mengaku pelatihan sesuai dengan kebutuhan peserta, 84.61\% peserta menyatakan bahwa pelatihan ini telah memberikan bekal kepada guruguru berupa ketrampilan pembuatan media pembelajaran, serta $92.30 \%$ peserta telah memperoleh manfaat/terbantukan dalam penyelesaiaan masalahnya dari pelaksanaan pelatihan. Pendampingan dilakukan sebanyak dua kali pada guru-guru di SMP Muhammadiyah 1 Godean. Dari pendampingan yang telah dilakukan, guru mengungkapkan bahwa mereka sangat menikmati membuat media pembelajaran, namun ketika menggunakan moodle para guru masih mengalami kesulitan sehingga pendampingan yang dilakukan bisa membantu guru untuk memasukan materi kedalam moodle.

\section{SIMPULAN}

Berdasarkan kegiatan yang telah dilakukan dapat disimpulkan bahwa 1) Pelaksanaan pelatihan sangat mendukung kegiatan belajar mengajar guru di kelas, 2) guru-guru sangat bersemangat dalam melakukan pelatihan. Hal ini memberikan ide bahwa sangat perlu dilakukan pelatihan e-learning dengan menggunakan moodle yang dipadukan dengan geogebra bagi guru-guru Matematika di sekolah lain dengan harapan para guru mendapatkan bekal dalam meningkatkan kualitas pembelajaran Matematika. 
Fahmi, Pelatihan Kemampuan E-learning....75

\section{DAFTAR RUJUKAN}

Anitah, Sri. (2008). Media Pembelajaran. Surakarta: UNS Press

Hmelo. S. (2004). Problem-Based Learning: What and How Do Student Learn?. Educational Psychology Review, 16(3). 235-266

Hudojo, H. (1988). Mengajar Belajar Matematika. Departemen Pendidikan dan Kebudayaan: Jakarta.

I Kadek S, I Dewa Made. (2014). E-Learning Berbasis Moodle. Yogyakarta: Graha Ilmu

Kementrian Pendidikan Nasional. Peraturan Menteri Pendidikan Nasional nomor. 22 tahun 2006 tentang standar isi

NCTM (National Council of Teachers of Mathematics). (2000). Principles and Standards for School Mathematics. Amerika Serikat: NCTM.

Richardson, K \& Stein, C. (2008). Developing Spatial Sense and Communication Skills. Mathematics Teaching In The Middle School, 14(2). 101-107

Rohaeti, et al. 2014. Enhancingstudents' Mathematical Logical Thinking Ability and SelfRegulated Learning Through Problem-Based Learning. International Journal of Education, 8(1). 54-63 